\title{
Treatment strategies in childhood craniopharyngioma
}

\author{
Stéphanie Puget* \\ Department of Pediatric Neurosurgery, Necker Hospital, Université Paris Descartes, Paris, France
}

\author{
Edited by: \\ Jörg Flitsch, University Hospital \\ Hamburg-Eppendorf, Germany \\ Günter K. Karl Stalla, \\ Max-Planck-Institute of Psychiatry, \\ Germany \\ Reviewed by: \\ Edward Raymond Laws, Brigham and \\ Women's Hospital, USA \\ *Correspondence: \\ Stéphanie Puget, Department of \\ Pediatric Neurosurgery, Necker \\ Hospital, Université Paris Descartes, \\ 149 rue de Sèvres, Sorbonne Paris \\ Cité, Paris 75015, France. \\ e-mail: stephanie.puget@gmail.com
}

\begin{abstract}
The surgical management of craniopharyngiomas in children remains one of the more controversial topics in pediatric neurosurgery. Theoretically, the benign histology implies that total surgical excision would be sufficient to provide a cure. It has been widely established however, that in certain cases total excision may lead to unacceptable hypothalamic injury. The therapeutic goals for pediatric craniopharyngiomas therefore, require not just cure of the disease but also preservation of function. Over the last 15 years, there has been a growing worldwide advocacy for less extensive resection and for the utilization of multimodality therapy to limit morbidity. With this in mind, risk-adapted strategies designed to preserve hypothalamic structures have been developed. The preliminary results of these strategies appear to be encouraging. However, the long-term clinical outcome in terms of post irradiation complications and management of relapses is currently unknown.
\end{abstract}

Keywords: craniopharyngioma, children, surgery, radiotherapy, hypothalamus, quality of life

\section{TRADITIONAL SURGICAL APPROACH}

Surgery for craniopharyngiomas has long been undertaken with a degree of trepidation related in part to their intimate association to the hypothalamus and their tendency to be calcified. Resection of these lesions therefore became a testament to surgical prowess (Yasargil et al., 1990).

Historically, the fact that craniopharyngiomas are histologically benign made them an ideal target for curative radical surgical resection with one of the key goals being preservation of vision. This was particularly so at the beginning of the microsurgical era (Hoffman et al., 1977; Choux and Lena, 1979; Yasargil et al., 1990; Villani et al., 1997; Van Effenterre and Boch, 2002). Subsequent recognition of appropriate surgical approaches and the additional use of modern technologies including ultrasonic aspiration tools, image-guided techniques, and neuroendoscopy further enhanced the surgeon's ability to attain radical resection such that craniopharyngioma surgery reached a peak of enthusiasm during the 1990s. Leading figures such as Hoffman et al. (1992), Choux and Lena (1979), Pierre-Kahn et al. (1988), Caldarelli et al. (1998), and Zuccaro (2005) published large pediatric surgical series showing their surgical success in resecting craniopharyngiomas.

\section{CRITICISM OF THE TRADITIONAL SURGICAL APPROACH}

Following this enthusiasm for gross total resection, the associated mortality (up to $50 \%$ at 10 years) and the high rate of recurrence despite surgical clearance (up to $50 \%$ in some series) became apparent (Shapiro et al., 1979; Carmel et al., 1982; McLone et al., 1982; Sung, 1982; Till, 1982; Pierre-Kahn et al., 1988; Fischer et al., 1990; Yasargil et al., 1990; Hoffman et al., 1992; Hetelekidis et al., 1993; Tomita and McLone, 1993; De Vile et al., 1996b; Zuccaro et al., 1996; Villani et al., 1997; Caldarelli et al., 1998; Zuccaro, 2005).

Endocrine disorders associated with radical resection of these tumors were considered both inevitable and "acceptable." Progress in endocrinological medicine had enabled hormonal replacement that was thought to be compatible with a "normal life" (Brauner et al., 1987; Honegger et al., 1999). Endocrine dysfunction was reported in up to $75 \%$ of affected children at presentation with the most frequent being growth hormone deficiency (Thomsett et al., 1980; Brauner et al., 1987; Tomita and McLone, 1993; Villani et al., 1997; Van Effenterre and Boch, 2002). Diabetes insipidus was less frequent at diagnosis (6-35\%) but its prevalence dramatically increased post-operatively $(50-100 \%)$ as did panhypopituitarism (75\%; Choux and Lena, 1979; Thomsett et al., 1980; Brauner et al., 1987; Yasargil et al., 1990; Hoffman et al., 1992; Tomita and McLone, 1993; Weiner et al., 1994; Crotty et al., 1995; Blethen et al., 1996; De Vile et al., 1996b; Zuccaro et al., 1996; Villani et al., 1997; Van Effenterre and Boch, 2002; Puget et al., 2007).

Peri-operative injury to the hypothalamus, incompatible with normal life due to hyperphagia, obesity, behavioral and memory disorders, loss of neurovegetative homeostasis, and an altered neuropsychological profile were also recognized (Fisher et al., 1998; Riva et al., 1998; Muller et al., 2005a; Pierre-Kahn et al., 2005; Puget et al., 2007; Bawden et al., 2009). Obesity was reported in $4-58 \%$ of children with craniopharyngiomas at diagnosis (Choux and Lena, 1979; Cabezudo et al., 1981; Carmel et al., 1982; Brauner et al., 1987; Hoffman et al., 1992; Tomita and McLone, 1993; Weiner et al., 1994; De Vile et al., 1996b; Zuccaro et al., 1996; Villani et al., 1997; Riva et al., 1998; Puget et al., 2007) but its prevalence increased dramatically, up to $81 \%$, following surgery particularly when radical surgery had been attempted (Brauner et al., 1987; Yasargil et al., 1990; Hoffman et al., 1992; De Vile et al., 1996b; Villani et al., 1997; Riva et al., 1998; Hayward, 1999; Puget et al., 2007). De Vile et al. (1996a) showed that this obesity was related to peri-operative hypothalamic injury.

Up to $50 \%$ of children had evidence of memory and behavioral disorders following craniopharyngioma surgery. Post-operative performance scores of 1 (excellent) and 2 (good) were reported in 53-73 and 66-92\% respectively, after gross total resection and partial resection with radiotherapy. These complications, associated 
with aggressive surgical removal and the degree of hypothalamic dysfunction, had an impact on quality of life (Clopper et al., 1977; Hoffman et al., 1977; Cavazzuti et al., 1983; De Vile et al., 1996a; Anderson et al., 1997; Villani et al., 1997; Donnet et al., 1999; Habrand et al., 1999; Carpentieri et al., 2001; Merchant et al., 2002; Poretti et al., 2004; Pierre-Kahn et al., 2005; Sands et al., 2005; Dekkers et al., 2006; Karavitaki et al., 2006; Puget et al., 2007; Muller, 2011).

The recognition of hypothalamic involvement as the main factor associated with morbidity led many groups to develop treatment strategies to avoid hypothalamic injury (Cavazzuti et al., 1983; De Vile et al., 1996a; Fisher et al., 1998; Riva et al., 1998; Carpentieri et al., 2001; Muller et al., 2001; Poretti et al., 2004; Pierre-Kahn et al., 2005; Puget et al., 2007; Ondruch et al., 2011). Peri-operative factors that could predict hypothalamic injury were identified (De Vile et al., 1996a; Merchant et al., 2002; Albright et al., 2005; Marchal et al., 2005; Muller et al., 2005b, 2006; Thompson et al., 2005; Spoudeas et al., 2006; Garre and Cama, 2007; Puget et al., 2007). Several teams then utilized progress within radiotherapy, such as conformal planning and proton beam therapy, and built these into treatment strategies of multimodality therapy (Hayward, 1999; Merchant et al., 2002; Rutka, 2002; Spoudeas et al., 2006; Puget et al., 2007).

\section{A NEW ERA OF SURGICAL MANAGEMENT WITH PRESERVATION OF HYPOTHALAMIC STRUCTURES}

Initial craniopharyngioma management is tailored to presentation. Raised intracranial pressure or rapid visual loss is managed by treating the associated hydrocephalus and/or tumor cyst decompression. Purely cystic tumors may be managed with the placement of a catheter to allow repeated aspiration. The use of intracystic radiotherapy (Yttrium-90 and Phosphorus-32) or chemotherapy with Bleomycin has not proven to be consistently efficacious (Voges et al., 1997; Albright et al., 2005; Marchal et al., 2005; Takahashi et al., 2005; Steinbok and Hukin, 2010). With resolution of the intracranial hypertension, two-thirds of patients will experience visual improvement (Garre and Cama, 2007).

Surgical resection of craniopharyngiomas is traditionally performed via a transcranial route. The advent of the endoscope enabled utilization of a trans-nasal route with the latter having been claimed to avoid hypothalamic dysfunction (Fahlbusch et al., 1999; Zona and Spaziante, 2006). It should be noted however, that the majority of tumors approached via this route were infra diaphragmatic in location (Jane et al., 2010). The morbidity associated with transcranial resection of craniopharyngiomas is largely dependent on tumor location and may be modified by the surgical approach and treatment strategy. Thompson et al. (2005) reported their results in terms of morbidity, mortality, and tumor recurrence when comparing two series of patients, one where the goal was total resection versus one where the aim was to improve quality of life and reduce morbidity. Using a scoring grade for vision, cognition, motor function, hypothalamic dysfunction, and endocrine disturbances, they concluded that they were able to improve quality of outcome without compromising tumor recurrence in their latter series of patients.

In an attempt to analyze the role of aggressive surgical resection relative to the risk of significant morbidity associated with this approach, the authors critically reviewed a retrospective series where there had been an intention of gross total resection in all cases (Puget et al., 2007). Classification of tumors at presentation was performed in order to rationalize multimodality therapy. Specifically, the pre- and post-operative MRI were graded with respect to the degree of hypothalamic involvement/injury (Figures 1 and 2). As previously shown (De Vile et al., 1996a), it was confirmed that quality of life outcomes (using the Health Utility Index 2, HUI2) were correlated with the degree of hypothalamic injury as evident on the post-operative MRI $(p=0.003)$. The post-operative BMI and quality of life were linked to hypothalamic involvement as assessed on the pre-operative MRI $(p=0.007$ and $p=0.001$ for BMI $Z$ score and HUI2 score respectively). This finding has subsequently been confirmed in a large, multicentre prospective study where the only independent risk factor for severe obesity, on multivariate analysis, was the degree of pre-operative hypothalamic involvement ( $p=0.002$; Muller et al., 2011) Using the MRI grading scheme described above (Puget et al., 2007). Van Gompel et al. (2010) in a large cohort of 296 adult patients, showed a good correlation between the degree of pre-operative hypothalamic involvement and post-operative weight gain $(p=0.022)$.

The likelihood of hypothalamic damage may be predicted by the degree of pre-operative hypothalamic involvement and
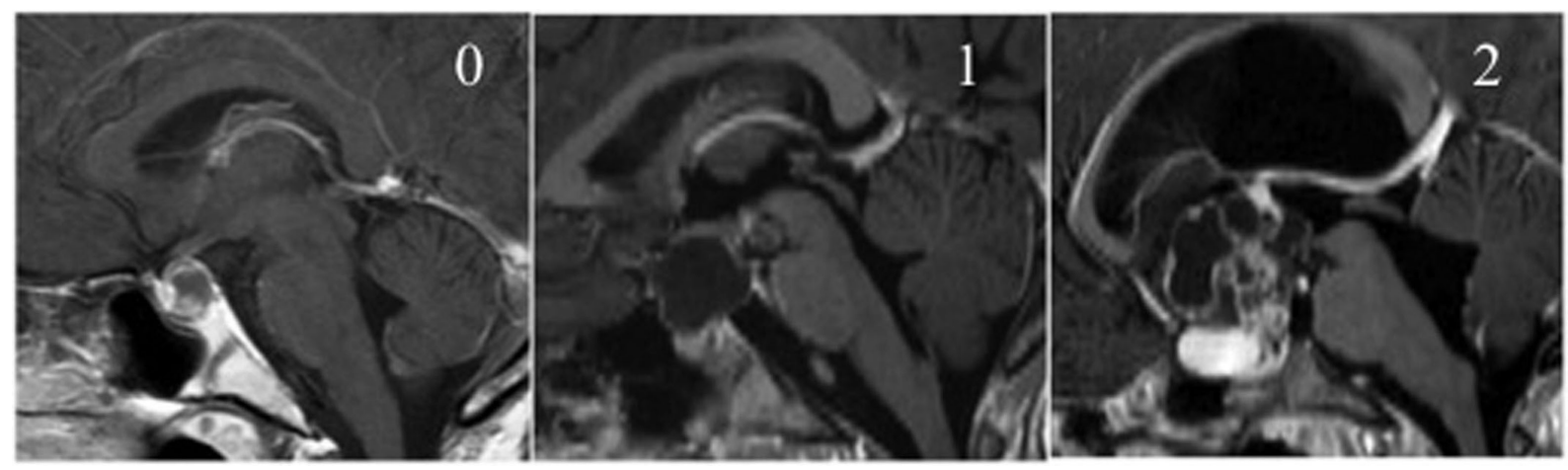

FIGURE 1 | Pre-operative MRI classification according to hypothalamic involvement. Type 0 pre-op: no involvement of the hypothalamus, Type 1 pre-op: distortion/elevation of the hypothalamus, Type 2 pre-op: the hypothalamus is not visible due to tumor invasion. 


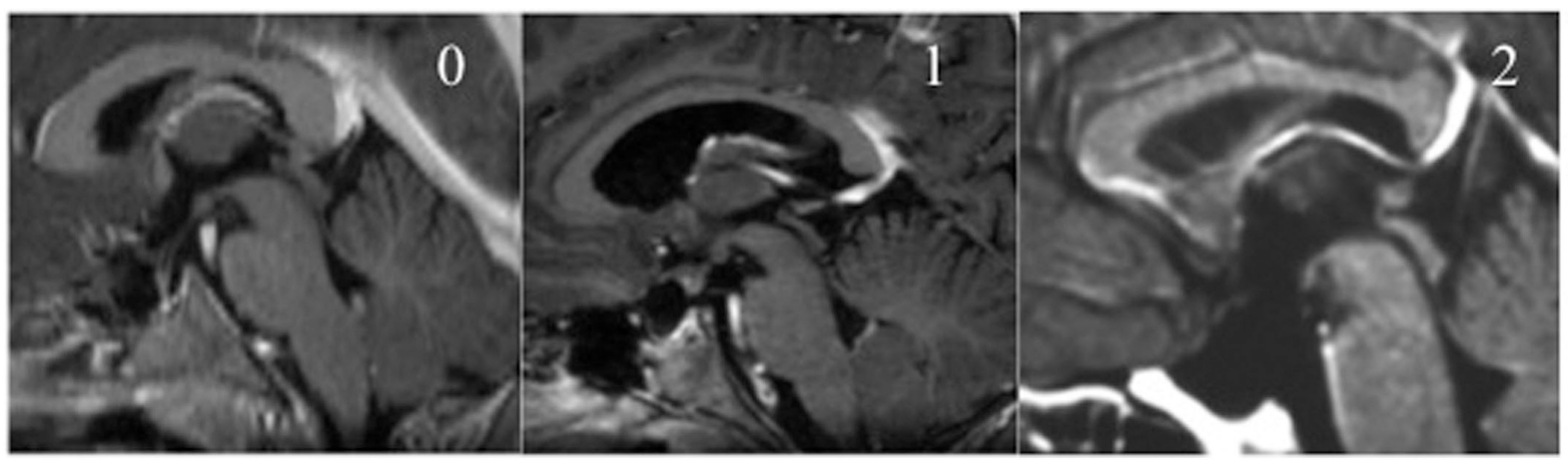

FIGURE 2 | Post-operative MRI classification according to hypothalamic injury. Type 0 post-op: intact hypothalamus, Type 1 post-op: breech/residue on the hypothalamus, Type 2 post-op: severe hypothalamic injury.

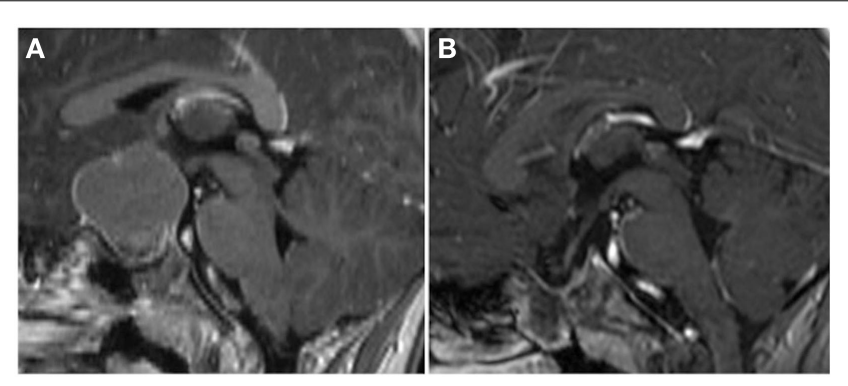

FIGURE 3 | Surgical strategy grade $\mathbf{0 / 1}$ pre-op. (A) On the pre-operative MRI, the hypothalamus appeared to be more displaced than invaded by tumor (Type 1 pre-op). (B) This was confirmed during surgery and a complete removal preserving the hypothalamus could be achieved (Type 0 post-op).

surgical skill (Sanford, 1994; Boop, 2007; Puget et al., 2007). Treatment strategies should therefore be adapted to the degree of pre-operative hypothalamic involvement, MRI type 0,1 , and 2 , in order to minimize morbidity. For those where the craniopharyngioma does not involve the hypothalamus (type 0 pre-op), total resection is suitable (Figure 3); when the tumor compresses the hypothalamus (type 1 pre-op), total resection may still be the best solution. However, the outcome will depend on the surgeon's skill in this domain. Finally, when the tumor involves the hypothalamus (type 2 pre-op), subtotal resection with respect to the involved hypothalamus combined with local irradiation currently appears to be the better option (Figure 4).

This surgical strategy was analyzed in a prospective series of 70 childhood craniopharyngiomas treated in our institution since 2002. Based on the above algorithm, half of the patients had a total removal; the others received radiotherapy after incomplete removal. We observed a significant statistical decrease in morbid obesity and in BMI $Z$ scores in our prospective series when compared to the historical cohort (publication in press).

Children treated with an intention to avoid hypothalamic injury had less endocrine dysfunction than those previously reported in pure surgical series. Questions are starting to be raised about the "normality" achieved despite hormone replacement as
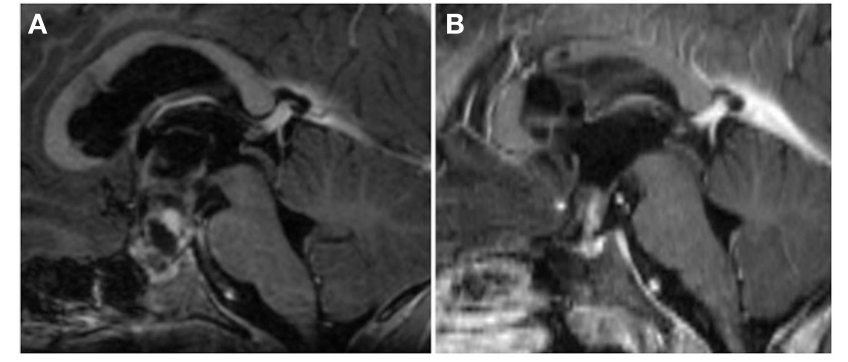

FIGURE 4 | Surgical strategy grade 2 pre-op. (A) At referral, the patient had severe intracranial hypertension secondary to obstructive hydrocephalus from a large intraventricular cyst of the third ventricle. An Ommaya reservoir was placed within the cyst as a matter of urgency. The tumor clearly invaded the hypothalamus (Type 2 pre-op) therefore the goal of surgery was to perform a subtotal removal leaving that component. (B) The residual lesion, attached to the infundibulum, which could not safely be removed.

more subtle issues such as fertility, adult growth hormone deficiency, and its association with low bone mineral density are being critically reviewed (Islas Cruz et al., 2004; Poretti et al., 2004; Holmer et al., 2011).

\section{THE ROLE OF RADIOTHERAPY}

In a recent extensive review of the literature, Kiehna showed that radiotherapy may provide long-term tumor control for pediatric craniopharyngiomas, with the more recent studies reporting at least $80 \%$ disease control at 10-years (Habrand et al., 2006; Kiehna and Merchant, 2010) and a favorable functional outcome in 42$86 \%$ of cases (Kiehna and Merchant, 2010). The main criticism of incorporating radiotherapy into a treatment strategy has been the well documented associated risks of late-onset vascular damage (particularly Moya-Moya syndrome; Sanford, 1994), secondary tumor genesis (Kranzinger et al., 2001; Caldarelli et al., 2005; Aquilina et al., 2010), and late cognitive effects (Merchant, 2006). Merchant et al. (2002) found a significant difference in full-scale IQ following gross total resection compared to limited resection followed by irradiation ( 9.8 points versus 1.25 respectively). They 
also showed that IQ remained stable over 5 years of follow-up (Merchant, 2006).

Conformal radiation therapy is currently considered the most appropriate radiation technique for this disease inducing less neurocognitive dysfunction when compared to conventional external beam radiotherapy (Kiehna et al., 2006; Scarzello et al., 2006; Minniti et al., 2007; Kiehna and Merchant, 2010) with favorable outcomes occurring in at least $85 \%$ of children (Merchant et al., 2002). There is a growing interest in proton beam irradiation in this disease with its potential to reduce the incidence of neurocognitive disorders and the late effects of irradiation to the optic pathway and hypothalamus. Preliminary results are promising (Baumert et al., 2004; Fitzek et al., 2006; Luu et al., 2006). For Merchant and his team, proton therapy has the potential to significantly reduce whole-brain and -body irradiation (Beltran et al., 2012) and, using dose-cognitive effects models, have shown that a reduction in the lower-dose volumes or mean dose would have long-term, clinical advantage for children with craniopharyngiomas (Merchant et al., 2008). They also compared photon- and proton-based irradiation methods to determine the effect of tumor volume change on target coverage and normal tissue irradiation in craniopharyngiomas. They have shown that proton therapy efficacy and safety is highly sensitive to target volume changes. In light of this and the findings of Merchant we believe that it is important that irradiation is targeted to a mostly solid lesion with cystic components aspirated or resected prior to irradiation.

The risk of progression following incomplete resection alone is $71-90 \%$ whereas it is estimated to be in the order of $15-20 \%$ when followed by radiotherapy (Fischer et al., 1990; Habrand et al., 1999; Kiehna and Merchant, 2010). Muller et al. (2011) has shown in a prospective multicentre analysis that the risk of progression was $88 \%$ lower in irradiated patients than in patients without radiotherapy. However long-term follow-up, beyond the 5- to 10years necessary to assess tumor recurrence relative to functional outcome, is lacking.

The most appropriate timing for radiotherapy following incomplete resection is still unknown. Moon et al. (2005) advocate early radiotherapy to improve quality of life rather than at tumor progression with further surgery and a potentially worse outcome. The optimal timing to prevent tumor recurrence following incomplete resection is currently being investigated in an international trial (Muller et al., 2011). This issue is of critical interest as the natural history of craniopharyngioma residua remains unpredictable with currently no clinical, radiological, or histological features able to differentiate those which will behave aggressively from those which will stay quiescent for many years.

\section{REFERENCES}

Albright, A. L., Hadjipanayis, C. G., Lunsford, L. D., Kondziolka, D., Pollack, I. F., and Adelson, P. D. (2005). Individualized treatment of pediatric craniopharyngiomas. Childs Nerv. Syst. 21, 649-654.

Anderson, C. A., Wilkening, G. N., Filley, C. M., Reardon, M. S., and Kleinschmidt-Demasters, B. K. (1997). Neurobehavioral outcome in pediatric craniopharyngioma. Pediatr. Neurosurg. 26, 255-260.

Aquilina, K., Merchant, T. E., Rodriguez-Galindo, C., Ellison, D. W., Sanford, R. A., and Boop, F. A. (2010). Malignant transformation of irradiated craniopharyngioma in children: report of 2 cases. J. Neurosurg. Pediatr. 5, 155-161.

Baumert, B. G., Norton, I. A., Lomax, A. J., and Davis, J. B. (2004).

\section{THE ROLE OF BIOLOGY}

The identification of specific biological markers of aggressiveness may therefore help to stratify patients and guide the development of risk-adapted strategies and novel treatments. To date, only a few studies have given insight into craniopharyngioma biology. Kato et al. (2004) showed nuclear/cytoplasmic accumulation of $\beta$ catenin in typical adamantinomatous type craniopharyngiomas. Moreover, $\beta$-catenin mutations have been found in a subset of adamantinomatous type craniopharyngiomas but not in other pituitary tumors (Sekine et al., 2002; Kato et al., 2004; Oikonomou et al., 2005). These findings suggest that the pathogenesis of pediatric craniopharyngiomas is associated with abnormalities of Wnt signaling, but thus far is unable to predict craniopharyngioma progression. Interestingly, in a mixed series of adults and pediatric craniopharyngiomas, Lefranc et al. (2003) found low levels of retinoic acid receptor $\beta(\operatorname{RAR} \beta)$, galectin-3, and Macrophage migration Inhibitory Factor (MIF) and high levels of retinoic acid receptor $\gamma(\mathrm{RAR} \gamma)$ to be associated with a higher risk of relapse. The role of these proteins in craniopharyngioma pathogenesis is still unclear. The role of estrogen and progesterone receptors (ER and $\mathrm{PR}$ respectively) has been described in another mixed series (Izumoto et al., 2005) showing that positive immunostaining for these markers was inversely linked with the risk of relapse. The main criticism of these papers is the lack of multivariate analyses and the lack of analysis of the quality of resection.

\section{CONCLUSION}

The morbidity and mortality after total resection of pediatric craniopharyngioma is well documented. There is an increasing advocacy among experts for limited resection followed by radiotherapy in specific cases. With a more conservative approach becoming universally adopted it is important not to ignore those who present as an absolute surgical emergency with hydrocephalus or chiasmatic compression. Total resection must remain the goal for those craniopharyngiomas that do not involve hypothalamic structures. For the rest, we now have a wealth of knowledge and modern techniques in imaging, surgery, and radiotherapy at our disposal to customize treatment thereby avoiding hypothalamic injury with its consequent devastating effects. In the swinging pendulum from aggressive to conservative treatment (Sainte-Rose et al., 2005), we need to be cognizant not only of our surgical limitations but also the limitations of other treatment modalities.

\section{ACKNOWLEDGMENTS}

We thank Dr. Maixner for her help in editing.

Dose conformation of intensitymodulated stereotactic photon beams, proton beams, and intensitymodulated proton beams for intracranial lesions. Int. J. Radiat. Oncol. Biol. Phys. 60, 1314-1324.

Bawden, H. N., Salisbury, S., Eskes, G. and Morehouse, R. (2009). Neuropsychological functioning following craniopharyngioma removal. J. Clin. Exp. Neuropsychol. 31, 140-144.
Beltran, C., Roca, M., and Merchant, T. E. (2012). On the benefits and risks of proton therapy in pediatric craniopharyngioma. Int. J. Radiat. Oncol. Biol. Phys. 82, e281-e287.

Blethen, S. L., Breen, T. J., and Attie, K. M. (1996). Overview of the national cooperative growth study substudy of serial growth hormone measurements. J. Pediatr. 128, S38-S41.

Boop, F. A. (2007). Craniopharyngioma. J. Neurosurg. 106, 1-2. [Discussion]. 
Brauner, R., Malandry, F., Rappaport, R., Pierre-Kahn, A., and Hirsch, J. F. (1987). Craniopharyngioma in children. Endocrine evaluation and treatment. Apropos of 37 cases. Arch. Fr. Pediatr. 44, 765-769.

Cabezudo, J. M., Vaquero, J., Areitio, E., Martinez, R., De Sola, R. G., and Bravo, G. (1981). Craniopharyngiomas: a critical approach to treatment. J. Neurosurg. 55, 371-375.

Caldarelli, M., Di Rocco, C., Papacci, F., and Colosimo, C. Jr. (1998). Management of recurrent craniopharyngioma. Acta Neurochir. (Wien) 140, 447-454.

Caldarelli, M., Massimi, L., Tamburrini, G., Cappa, M., and Di Rocco, C. (2005). Long-term results of the surgical treatment of craniopharyngioma: the experience at the Policlinico Gemelli, Catholic University, Rome. Childs Nerv. Syst. 21, 747-757.

Carmel, P. W., Antunes, J. L., and Chang, C. H. (1982). Craniopharyngiomas in children. Neurosurgery 11 , 382-389.

Carpentieri, S. C., Waber, D. P., Scott, R. M., Goumnerova, L. C., Kieran, M. W., Cohen, L. E., Kim, F., Billett, A. L., Tarbell, N. J., and Pomeroy, S. L. (2001). Memory deficits among children with craniopharyngiomas. Neurosurgery 49, 1053-1057. [Discussion].

Cavazzuti, V., Fischer, E. G., Welch, K., Belli, J. A., and Winston, K. R. (1983). Neurological and psychophysiological sequelae following different treatments of craniopharyngioma in children. J. Neurosurg. 59, 409-417.

Choux, M., and Lena, G. (1979). Bases of surgical management of craniopharyngioma in children [proceedings]. Acta Neurochir. Suppl. (Wien) 28, 348 .

Clopper, R. R., Meyer, W. J. III, Udvarhelyi, G. B., Money, J., Aarabi, B., Mulvihill, J. J., and Piasio, M. (1977). Postsurgical IQ and behavioral data on twenty patients with a history of childhood craniopharyngioma. Psychoneuroendocrinology 2, 365-372.

Crotty, T. B., Scheithauer, B. W., Young, W. F. Jr., Davis, D. H., Shaw, E. G., Miller, G. M., and Burger, P. C. (1995). Papillary craniopharyngioma: a clinicopathological study of 48 cases. J. Neurosurg. 83, 206-214.

De Vile, C. J., Grant, D. B., Hayward, R. D., Kendall, B. E., Neville, B. G., and Stanhope, R. (1996a). Obesity in childhood craniopharyngioma: relation to post-operative hypothalamic damage shown by magnetic resonance imaging. J. Clin. Endocrinol. Metab. 81, 2734-2737.

De Vile, C. J., Grant, D. B., Kendall, B. E., Neville, B. G., Stanhope, R., Watkins, K. E., and Hayward, R. D. (1996b). Management of childhood craniopharyngioma: can the morbidity of radical surgery be predicted? J. Neurosurg. 85, 73-81.

Dekkers, O. M., Biermasz, N. R., Smit, J. W., Groot, L. E., Roelfsema, F., Romijn, J. A., and Pereira, A. M. (2006). Quality of life in treated adult craniopharyngioma patients. Eur. J. Endocrinol. 154, 483-489.

Donnet, A., Schmitt, A., Dufour, H., and Grisoli, F. (1999). Neuropsychological follow-up of twenty two adult patients after surgery for craniopharyngioma. Acta Neurochir. (Wien) 141, 1049-1054.

Fahlbusch, R., Honegger, J., Paulus, W., Huk, W., and Buchfelder, M. (1999). Surgical treatment of craniopharyngiomas: experience with 168 patients. J. Neurosurg. 90, 237-250.

Fischer, E. G., Welch, K., Shillito, J. Jr., Winston, K. R., and Tarbell, N. J. (1990). Craniopharyngiomas in children. Long-term effects of conservative surgical procedures combined with radiation therapy. J. Neurosurg. 73, 534-540.

Fisher, P. G., Jenab, J., Gopldthwaite, P. T., Tihan, T., Wharam, M. D., Foer, D. R., and Burger, P. C. (1998). Outcomes and failure patterns in childhood craniopharyngiomas. Childs Nerv. Syst. 14, 558-563.

Fitzek, M. M., Linggood, R. M., Adams, J., and Munzenrider, J. E. (2006). Combined proton and photon irradiation for craniopharyngioma: long-term results of the early cohort of patients treated at Harvard Cyclotron Laboratory and Massachusetts General Hospital. Int. J. Radiat. Oncol. Biol. Phys. 64, 1348-1354.

Garre, M. L., and Cama, A. (2007). Craniopharyngioma: modern concepts in pathogenesis and treatment. Curr. Opin. Pediatr. 19, 471-479.

Habrand, J. L., Ganry, O., Couanet, D., Rouxel, V., Levy-Piedbois, C., Pierre-Kahn, A., and Kalifa, C. (1999). The role of radiation therapy in the management of craniopharyngioma: a 25-year experience and review of the literature. Int. J. Radiat. Oncol. Biol. Phys. 44, 255-263.

Habrand, J. L., Saran, F., Alapetite, C., Noel, G., El Boustany, R., and Grill, J. (2006). Radiation therapy in the management of craniopharyngioma: current concepts and future developments. J. Pediatr. Endocrinol. Metab. 19(Suppl. 1), 389-394.

Hayward, R. (1999). The present and future management of childhood craniopharyngioma. Childs Nerv. Syst. 15, 764-769.

Hetelekidis, S., Barnes, P. D., Tao, M. L., Fischer, E. G., Schneider, L., Scott, R. M., and Tarbell, N. J. (1993). 20year experience in childhood craniopharyngioma. Int. J. Radiat. Oncol. Biol. Phys. 27, 189-195.

Hoffman, H. J., De Silva, M., Humphreys, R. P., Drake, J. M., Smith, M. L., and Blaser, S. I. (1992) Aggressive surgical management of craniopharyngiomas in children. $J$. Neurosurg. 76, 47-52.

Hoffman, H. J., Hendrick, E. B., Humphreys, R. P., Buncic, J. R., Armstrong, D. L., and Jenkin, R. D. (1977). Management of craniopharyngioma in children. J. Neurosurg. 47, 218-227.

Holmer, H., Popovic, V., Ekman, B., Follin, C., Siversson, A. B., and Erfurth, E. M. (2011). Hypothalamic involvement and insufficient sex steroid supplementation are associated with low bone mineral density in women with childhood onset craniopharyngioma. Eur. J. Endocrinol. 165, 25-31.

Honegger, J., Buchfelder, M., and Fahlbusch, R. (1999). Surgical treatment of craniopharyngiomas: endocrinological results. $J$. Neurosurg. 90, 251-257.

Islas Cruz, G., Vite Vargas, J. A., Hernandez Marin, I., Aguirre Ramirez, A., Tovar Rodriguez, J. M., and Ayala Ruiz, A. R. (2004). Craniopharyngioma and its impact upon human reproduction: analysis of 15 cases at the Hospital Juarez de Mexico. Ginecol. Obstet. Mex. 72, 345-348.

Izumoto, S., Suzuki, T., Kinoshita, M., Hashiba, T., Kagawa, N., Wada, K., Fujimoto, Y., Hashimoto, N., Saitoh, Y., Maruno, M., and Yoshimine, T. (2005). Immunohistochemical detection of female sex hormone receptors in craniopharyngiomas: correlation with clinical and histologic features. Surg. Neurol. 63, 520-525. [Discussion].

Jane, J. A. Jr., Prevedello, D. M., Alden, T. D., and Laws, E. R. Jr. (2010). The transsphenoidal resection of pediatric craniopharyngiomas: a case series. J. Neurosurg. Pediatr. 5, 49-60.

Karavitaki, N., Cudlip, S., Adams, C. B., and Wass, J. A. (2006).
Craniopharyngiomas. Endocr. Rev. 27, 371-397.

Kato, K., Nakatani, Y., Kanno, H., Inayama, Y., Ijiri, R., Nagahara, N., Miyake, T., Tanaka, M., Ito, Y., Aida, N., Tachibana, K., Sekido, K., and Tanaka, Y. (2004). Possible linkage between specific histological structures and aberrant reactivation of the Wnt pathway in adamantinomatous craniopharyngioma. J. Pathol. 203, 814-821.

Kiehna, E. N., and Merchant, T. E. (2010). Radiation therapy for pediatric craniopharyngioma. Neurosurg. Focus 28, E10.

Kiehna, E. N., Mulhern, R. K., Li, C., Xiong, X., and Merchant, T. E. (2006). Changes in attentional performance of children and young adults with localized primary brain tumors after conformal radiation therapy. J. Clin. Oncol. 24, 5283-5290.

Kranzinger, M., Jones, N., Rittinger, O., Pilz, P., Piotrowski, W. P., Manzl, M., Galvan, G., and Kogelnik, H. D. (2001). Malignant glioma as a secondary malignant neoplasm after radiation therapy for craniopharyngioma: report of a case and review of reported cases. Onkologie 24, 66-72.

Lefranc, F., Chevalier, C., Vinchon, M., Dhellemmes, P., Schuring, M. P., Kaltner, H., Brotchi, J., Ruchoux, M. M., Gabius, H. J., Salmon, I., and Kiss, R. (2003). Characterization of the levels of expression of retinoic acid receptors, galectin-3, macrophage migration inhibiting factor, and p53 in 51 adamantinomatous craniopharyngiomas. J. Neurosurg. 98, 145-153.

Luu, Q. T., Loredo, L. N., Archambeau, J. O., Yonemoto, L. T., Slater, J. M., and Slater, J. D. (2006). Fractionated proton radiation treatment for pediatric craniopharyngioma: preliminary report. Cancer J. 12, 155-159.

Marchal, J. C., Klein, O., Thouvenot, P., Bernier, V., Moret, C. and Chastagner, P. (2005). Individualized treatment of craniopharyngioma in children: ways and means. Childs Nerv. Syst. 21, 655-659.

McLone, D. G., Raimondi, A. J., and Naidich, T. P. (1982). Craniopharyngiomas. Childs Brain 9, 188-200.

Merchant, T. E. (2006). Craniopharyngioma radiotherapy: endocrine and cognitive effects. J. Pediatr. Endocrinol. Metab. 19(Suppl. 1), 439-446. 
Merchant, T. E., Hua, C. H., Shukla, H., Ying, X., Nill, S., and Oelfke, U. (2008). Proton versus photon radiotherapy for common pediatric brain tumors: comparison of models of dose characteristics and their relationship to cognitive function. Pediatr. Blood Cancer 51, 110-117.

Merchant, T. E., Kiehna, E. N., Sanford, R. A., Mulhern, R. K., Thompson, S. J., Wilson, M. W., Lustig, R. H., and Kun, L. E. (2002). Craniopharyngioma: the St. Jude Children's Research Hospital experience 1984-2001. Int. J. Radiat. Oncol. Biol. Phys. 53, 533-542.

Minniti, G., Saran, F., Traish, D., Soomal, R., Sardell, S., Gonsalves, A., Ashley, S., Warrington, J., Burke, K., MoslehShirazi, A., and Brada, M. (2007). Fractionated stereotactic conformal radiotherapy following conservative surgery in the control of craniopharyngiomas. Radiother. Oncol. 82, 90-95.

Moon, S. H., Kim, I. H., Park, S. W., Kim, I., Hong, S., Park, C. I., Wang, K. C., and Cho, B. K. (2005). Early adjuvant radiotherapy toward long-term survival and better quality of life for craniopharyngiomas-a study in single institute. Childs Nerv. Syst. 21, 799-807.

Muller, H. L. (2011). Consequences of craniopharyngioma surgery in children. J. Clin. Endocrinol. Metab. 96, 1981-1991.

Muller, H. L., Albanese, A., Calaminus, G., Hargrave, D., Garre, M. L., Gebhardt, U., Saran, F., Sorensen, N., and Spoudeas, H. A. (2006). Consensus and perspectives on treatment strategies in childhood craniopharyngioma: results of a meeting of the Craniopharyngioma Study Group (SIOP), Genova, 2004. J. Pediatr. Endocrinol. Metab. 19(Suppl. 1), 453-454.

Muller, H. L., Bruhnken, G., Emser, A., Faldum, A., Etavard-Gorris, N., Gebhardt, U., Kolb, R., and Sorensen, N. (2005a). Longitudinal study on quality of life in 102 survivors of childhood craniopharyngioma. Childs Nerv. Syst. 21, 975-980.

Muller, H. L., Gebhardt, U., EtavardGorris, N., Kolb, R., Warmuth-Metz, M., and Sorensen, N. (2005b). Current strategies in diagnostics and endocrine treatment of patients with childhood craniopharyngioma during follow-up-recommendations in KRANIOPHARYNGEOM 2000. Onkologie 28, 150-156.
Muller, H. L., Bueb, K., Bartels, U., Roth, C., Harz, K., Graf, N., Korinthenberg, R., Bettendorf, M., Kuhl, J., Gutjahr, P., Sorensen, N., and Calaminus, G. (2001). Obesity after childhood craniopharyngiomaGerman multicenter study on pre-operative risk factors and quality of life. Klin. Padiatr. 213, 244-249.

Muller, H. L., Gebhardt, U., Teske, C., Faldum, A., Zwiener, I., WarmuthMetz, M., Pietsch, T., Pohl, F., Sorensen, N., and Calaminus, G. (2011). Post-operative hypothalamic lesions and obesity in childhood craniopharyngioma: results of the multinational prospective trial KRANIOPHARYNGEOM 2000 after 3-year follow-up. Eur. J. Endocrinol. 165, 17-24.

Oikonomou, E., Barreto, D. C., Soares, B., De Marco, L., Buchfelder, M., and Adams, E. F. (2005). Beta-catenin mutations in craniopharyngiomas and pituitary adenomas. J. Neurooncol. 73, 205-209.

Ondruch, A., Maryniak, A., Kropiwnicki, T., Roszkowski, M., and Daszkiewicz, P. (2011). Cognitive and social functioning in children and adolescents after the removal of craniopharyngioma. Childs Nerv. Syst. 27, 391-397.

Pierre-Kahn, A., Brauner, R., Renier, D., Sainte-Rose, C., Gangemi, M. A., Rappaport, R., and Hirsch, J. F. (1988). Treatment of craniopharyngiomas in children. Retrospective analysis of 50 cases. Arch. Fr. Pediatr. 45, 163-167.

Pierre-Kahn, A., Recassens, C., Pinto, G., Thalassinos, C., Chokron, S., Soubervielle, J. C., Brauner, R., Zerah, M., and Sainte Rose, C. (2005). Social and psychointellectual outcome following radical removal of craniopharyngiomas in childhood. A prospective series. Childs Nerv. Syst. 21, 817-824.

Poretti, A., Grotzer, M. A., Ribi, K., Schonle, E., and Boltshauser, E. (2004). Outcome of craniopharyngioma in children: longterm complications and quality of life. Dev. Med. Child Neurol. 46, 220-229.

Puget, S., Garnett, M., Wray, A., Grill, J., Habrand, J. L., Bodaert, N., Zerah, M., Bezerra, M., Renier, D., Pierre-Kahn, A., and Sainte-Rose, C. (2007). Pediatric craniopharyngiomas: classification and treatment according to the degree of hypothalamic involvement. J. Neurosurg. 106 , 3-12.

Riva, D., Pantaleoni, C., Devoti, M., Saletti, V., Nichelli, F., and Giorgi, C. (1998). Late neuropsychological and behavioural outcome of children surgically treated for craniopharyngioma. Childs Nerv. Syst. 14, 179-184.

Rutka, J. T. (2002). Craniopharyngioma. J. Neurosurg. 97, 1-2. [Discussion].

Sainte-Rose, C., Puget, S., Wray, A., Zerah, M., Grill, J., Brauner, R., Boddaert, N., and Pierre-Kahn, A. (2005). Craniopharyngioma: the pendulum of surgical management. Childs Nerv. Syst. 21, 691-695.

Sands, S. A., Milner, J. S., Goldberg, J., Mukhi, V., Moliterno, J. A., Maxfield, C., and Wisoff, J. H. (2005). Quality of life and behavioral follow-up study of pediatric survivors of craniopharyngioma. J. Neurosurg. 103, 302-311.

Sanford, R. A. (1994). Craniopharyngioma: results of survey of the American Society of Pediatric Neurosurgery. Pediatr. Neurosurg. 21(Suppl. 1), 39-43.

Scarzello, G., Buzzaccarini, M. S., Perilongo, G., Viscardi, E., Faggin, R., Carollo, C., Calderone, M., Franchi, A., and Sotti, G. (2006). Acute and late morbidity after limited resection and focal radiation therapy in craniopharyngiomas. J. Pediatr. Endocrinol. Metab. 19(Suppl. 1), 399-405.

Sekine, S., Shibata, T., Kokubu, A., Morishita, Y., Noguchi, M., Nakanishi, Y., Sakamoto, M., and Hirohashi, S. (2002). Craniopharyngiomas of adamantinomatous type harbor beta-catenin gene mutations. Am. J. Pathol. 161, 1997-2001.

Shapiro, K., Till, K., and Grant, D. N. (1979). Craniopharyngiomas in childhood. A rational approach to treatment. J. Neurosurg. 50, 617-623.

Spoudeas, H. A., Saran, F., and Pizer, B. (2006). A multimodality approach to the treatment of craniopharyngiomas avoiding hypothalamic morbidity: a UK perspective. J. Pediatr. Endocrinol. Metab. 19(Suppl. 1), 447-451.

Steinbok, P., and Hukin, J. (2010). Intracystic treatments for craniopharyngioma. Neurosurg. Focus 28, E13.

Sung, D. I. (1982). Suprasellar tumors in children: a review of clinical manifestations and managements. Cancer 50, 1420-1425.
Takahashi, H., Yamaguchi, F., and Teramoto, A. (2005). Long-term outcome and reconsideration of intracystic chemotherapy with bleomycin for craniopharyngioma in children. Childs Nerv. Syst. 21, 701-704.

Thompson, D., Phipps, K., and Hayward, R. (2005). Craniopharyngioma in childhood: our evidence-based approach to management. Childs Nerv. Syst. 21, 660-668.

Thomsett, M. J., Conte, F. A., Kaplan, S. L., and Grumbach, M. M. (1980). Endocrine and neurologic outcome in childhood craniopharyngioma: review of effect of treatment in 42 patients. J. Pediatr. 97 $728-735$.

Till, K. (1982). Craniopharyngioma. Childs Brain 9, 179-187.

Tomita, T., and McLone, D. G. (1993). Radical resections of childhood craniopharyngiomas. Pediatr. Neurosurg. 19, 6-14.

Van Effenterre, R., and Boch, A L. (2002). Craniopharyngioma in adults and children: a study of 122 surgical cases. J. Neurosurg. 97, 3-11.

Van Gompel, J. J., Nippoldt, T. B., Higgins, D. M., and Meyer, F. B. (2010). Magnetic resonance imaging-graded hypothalamic compression in surgically treated adult craniopharyngiomas determining postoperative obesity. Neurosurg. Focus 28, E3.

Villani, R. M., Tomei, G., Bello, L., Sganzerla, E., Ambrosi, B., Re, T., and Giovanelli Barilari, M. (1997). Long-term results of treatment for craniopharyngioma in children. Childs Nerv. Syst. 13, 397-405.

Voges, J., Sturm, V., Lehrke, R., Treuer, H., Gauss, C., and Berthold, F. (1997). Cystic craniopharyngioma: long-term results after intracavitary irradiation with stereotactically applied colloidal beta-emitting radioactive sources. Neurosurgery 40, 263-269. [Discussion].

Weiner, H. L., Wisoff, J. H., Rosenberg, M. E., Kupersmith, M. J., Cohen, H., Zagzag, D., Shiminski-Maher, T., Flamm, E. S., Epstein, F. J., and Miller, D. C. (1994). Craniopharyngiomas: a clinicopathological analysis of factors predictive of recurrence and functional outcome. $\mathrm{Neu}$ rosurgery 35, 1001-1010. [Discussion].

Yasargil, M. G., Curcic, M., Kis, M., Siegenthaler, G., Teddy, P. J., and Roth, P. (1990). Total removal of craniopharyngiomas. 
Approaches and long-term results in 144 patients. J. Neurosurg. 73, 3-11.

Zona, G., and Spaziante, R. (2006). Management of cystic craniopharyngiomas in childhood by a transsphenoidal approach. J. Pediatr. Endocrinol. Metab. 19(Suppl. 1), 381-388.

Zuccaro, G. (2005). Radical resection of craniopharyngioma.
Childs Nerv. Syst. 21, commercial or financial relationships 679-690. that could be construed as a potential

Zuccaro, G., Jaimovich, R., Mantese, B., and Monges, J. (1996). Complications in paediatric craniopharyngioma treatment. Childs Nerv. Syst. 12, 385-390. [Discussion].

Conflict of Interest Statement: The author declares that the research was conducted in the absence of any conflict of interest.

Received: 07 November 2011; accepted: 24 April 2012; published online: 05 June 2012.

Citation: Puget S (2012) Treatment strategies in childhood craniopharyngioma. Front. Endocrin. 3:64. doi: 10.3389/fendo.2012.00064
This article was submitted to Frontiers in Pituitary Endocrinology, a specialty of Frontiers in Endocrinology.

Copyright (c) 2012 Puget. This is an open-access article distributed under the terms of the Creative Commons Attribution Non Commercial License, which permits non-commercial use, distribution, and reproduction in other forums, provided the original authors and source are credited. 